Nevada

Environmental

Restoration

Project

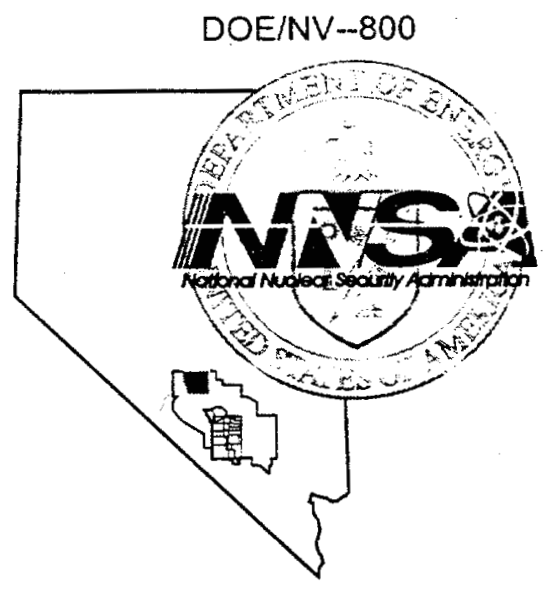

Post-Closure Inspection Report for Corrective Action Unit 424: Area 3 Landfill Complexes

Tonopah Test Range, Nevada Calendar Year 2001

Controlled Copy No.:

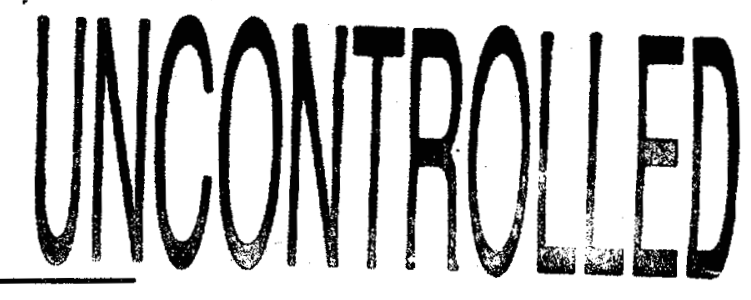

Revision: 0

January 2002

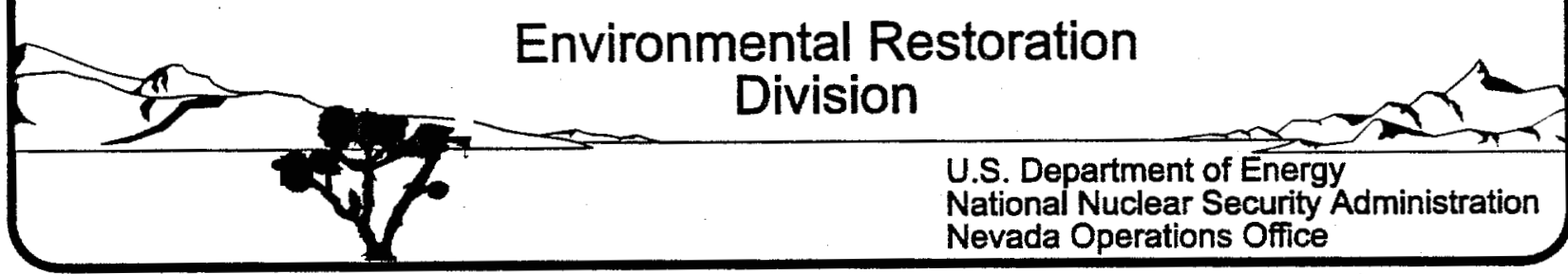




\section{DISCLAIMER STATEMENT}

Reference herein to any specific commercial product, process, or service by trade name, trademark, manufacturer, or otherwise, does not necessarily constitute or imply its endorsement. recommendation, or favoring by the U.S. Government or any agency thereof or its contractors or subcontractors.

\section{AVAILABILITY STATEMENT}

Available for sale to the public from-

U.S. Department of Commerce

National Technical Information Service

5285 Port Royal Road

Springfield, VA 22161-0002

Telephone: 800.553 .6847

Fax: 703.605.6900

E-mail: orders@ntis.fedworld.gov

Online ordering: http://www.ntis.gov/ordering.htm

Available electronically at http://www.doe.gov/bridge

Available for a processing fee to U.S. Department of Energy and its contractors, in paper, from-

U.S. Department of Energy

Office of Scientific and Technical Information

P.O. Box 62

Oak Ridge, TN 37831-0062

Telephone: 865.576 .8401

Fax: 865.576.5728

E-mail: reports@adonis.osti.gov 


\title{
POST-CLOSURE INSPECTION REPORT FOR CORRECTIVE ACTION UNIT 424: AREA 3 LANDFILL COMPLEXES TONOPAH TEST RANGE, NEVADA CALENDAR YEAR 2001
}

\author{
Prepared for \\ U. S. Department of Energy \\ National Nuclear Security Administration \\ Nevada Operations Office \\ Work Performed Under Contract No. \\ DE-AC08-96NV11718
}

Controlled Copy No.:

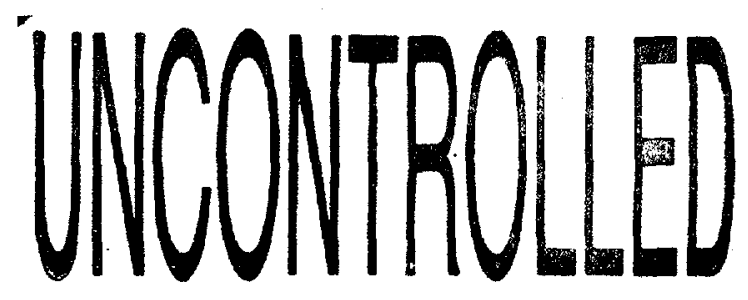

Revision: 0

January 2002 


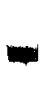

THIS PAGE INTENTIONALLY LEFT BLANK

$-$ 


\section{POST-CLOSURE INSPECTION REPORT FOR CORRECTIVE ACTION UNIT 424: AREA 3 LANDFILL COMPLEXES TONOPAH TEST RANGE, NEVADA CALENDAR YEAR 2001}

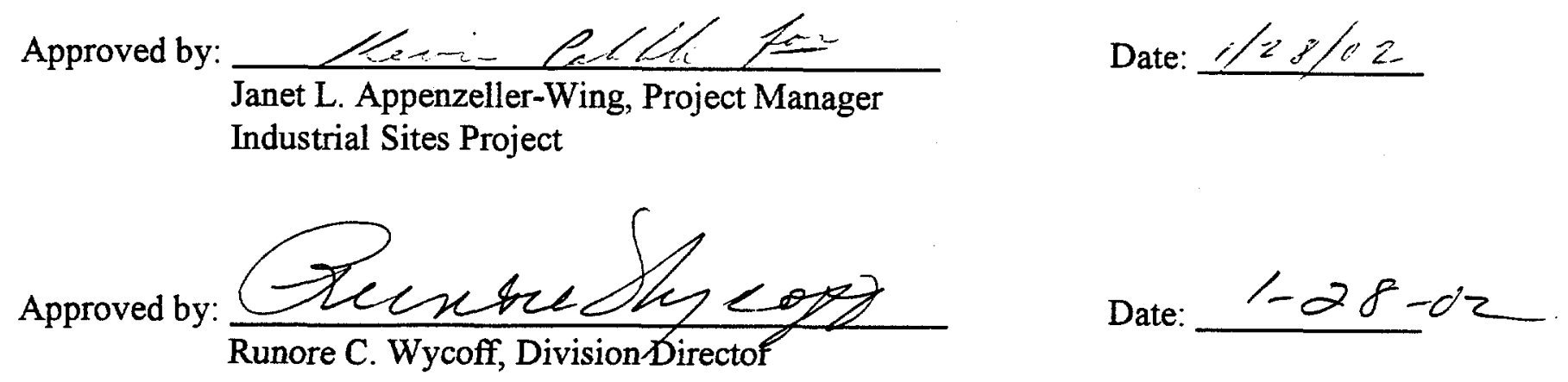


$-$ 


\title{
TABLE OF CONTENTS
}

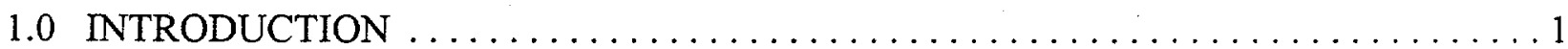

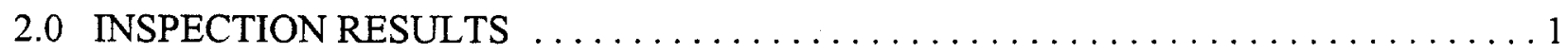

2.1 May 16,2001 Inspection . . . . . . . . . . . . . . . . . . . . . . . . . 4

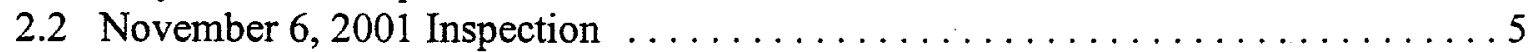

3.0 RECOMMENDATIONS AND CONCLUSIONS $\ldots \ldots \ldots \ldots \ldots \ldots \ldots$

\section{FIGURES}

FIGURE 1 - AREA 3 LANDFILL COMPLEXES CAU 424 LOCATION MAP . . . . . . . . 2

FIGURE 2 - LOCATIONS OF THE EIGHT AREA 3 LANDFILL SITES $\ldots \ldots \ldots \ldots \ldots$.

\author{
ATTACHMENTS \\ ATTACHMENT A - INSPECTION CHECKLISTS \\ ATTACHMENT B - FIELD NOTES \\ ATTACHMENT C - PHOTOGRAPH LOG AND PHOTOGRAPHS \\ DISTRIBUTION LIST
}


Post-Closure Inspection Report

(AL: NO +24

Area 3 Landfill Complexes

Revision: 0

Date: January 24, 2002

\section{THIS PAGE INTENTIONALLY LEFT BLANK}




\subsection{INTRODUCTION}

Corrective Action Unit (CAU) 424, the Area 3 Landfill Complexes at Tonopah Test Range, consists of eight Corrective Action Sites (CASs), seven of which are landfill cells that were closed previously by capping. (The eighth CAS, A3-7, was not used as a landfill site and was closed without taking any corrective action.) Figure 1 shows the general location of the landfill cells. Figure 2 shows in more detail the location of the eight landfill cells. CAU 424 closure activities included removing small volumes of soil containing petroleum hydrocarbons, repairing cell covers that were cracked or had subsided, and installing above-grade and at-grade monuments marking the corners of the landfill cells. Post-closure monitoring requirements for CAU 424 are detailed in Section 5.0, Post-Closure Inspection Plan, contained in the Closure Report for Corrective Action Unit 424: Area 3 Landfill Complexes, Tonopah Test Range, Nevada, report number DOE/NV--283, July 1999. The Closure Report (CR) was approved by the Nevada Division of Environmental Protection (NDEP) in July 1999. The CR includes compaction and permeability results of soils that cap the seven landfill cells.

As stated in Section 5.0 of the NDEP-approved CR, post-closure monitoring at CAU 424 consists of the following:

- $\quad$ Site inspections conducted twice a year to evaluate the condition of the unit.

- Verification that landfill markers and warning signs are in-place, intact, and readable..

- $\quad$ Notice of any subsidence, erosion, unauthorized use, or deficiencies that may compromise the integrity of the landfill covers.

- Remedy of any deficiencies within 90 days of discovery.

- Preparation and submittal of an annual report.

Site inspections were conducted on May 16, 2001, and November 6, 2001. The inspections were preformed after the NDEP approval of the CR.

This report includes copies of the inspection checklist, photographs, recommendations, and conclusions. The Post-Closure Inspection Checklists are found in Attachment A, a copy of the field notes is found in Attachment B, and copies of the inspection photographs are found in Attachment $\mathrm{C}$.

\subsection{INSPECTION RESULTS}

The following observations were made during the 2001 site inspections of the seven individual landfill units (CASs) that comprise CAU 424. 

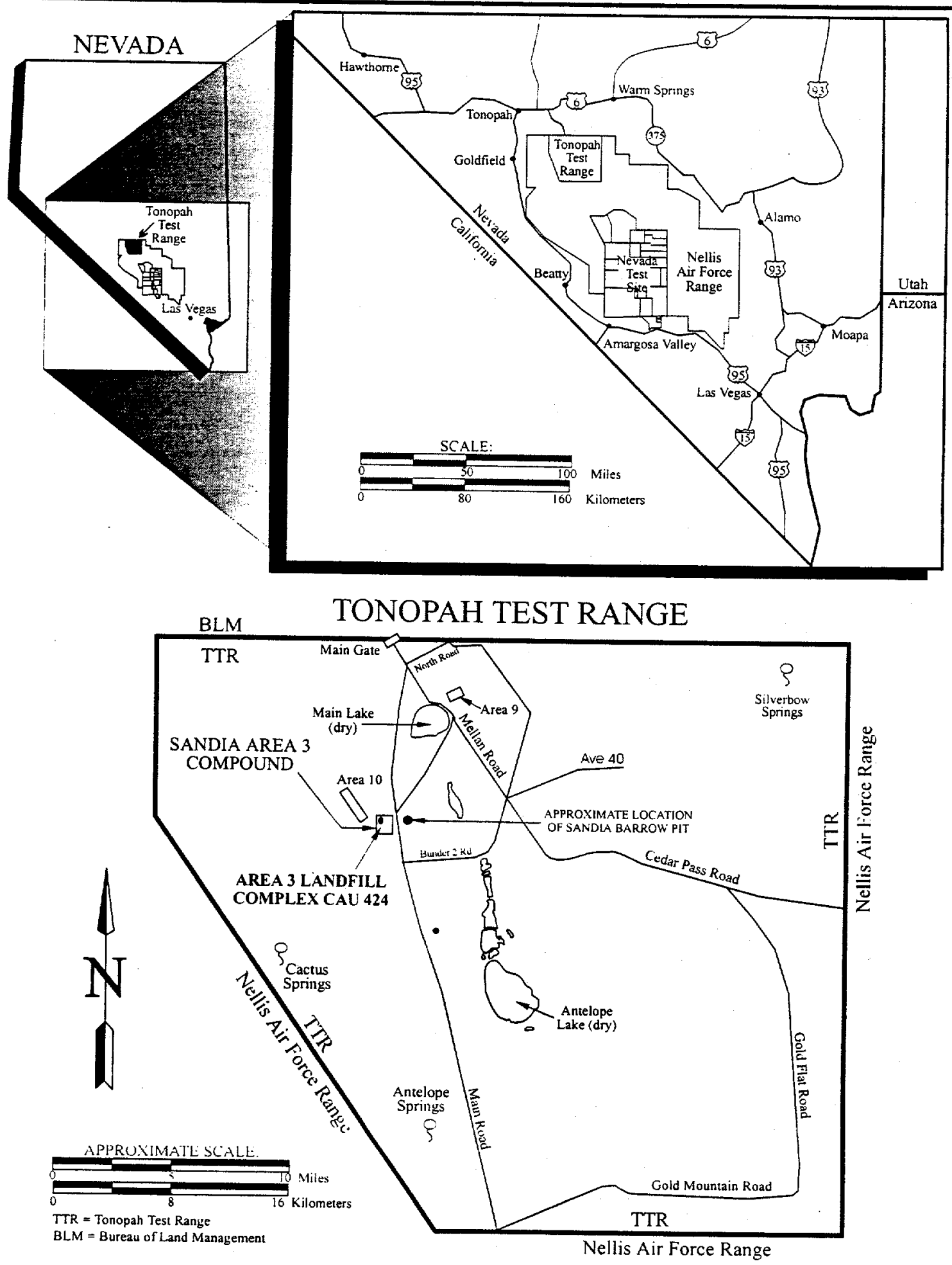

FIGURE 1

AREA 3 LANDFILL COMPLEXES

CAU 424 LOCATION MAP 


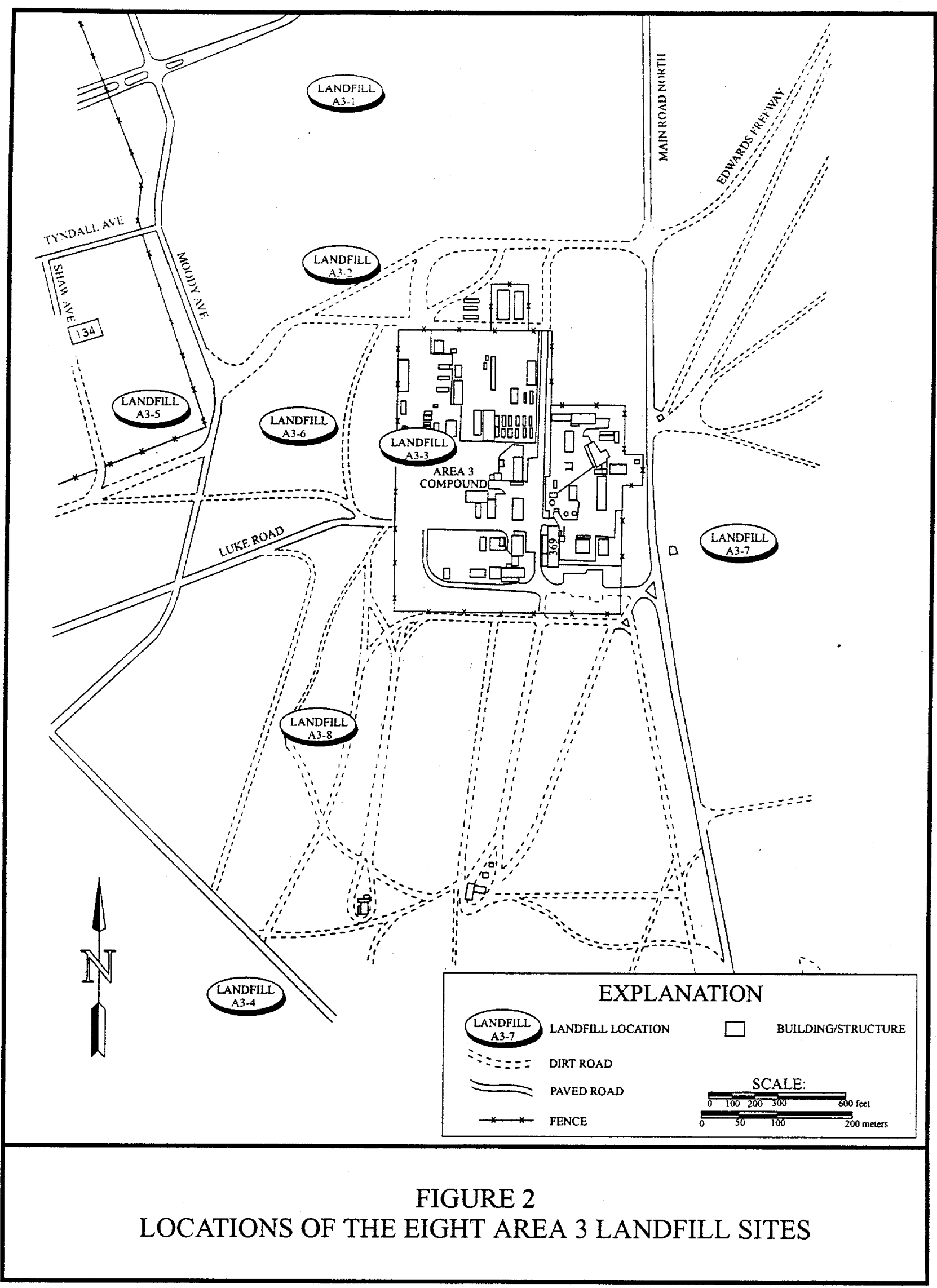




\subsection{May 16, 2001 Inspection}

The first inspection of CAU 424 was conducted on May 16, 2000. None of the seven landfill units were fenced at closure and are accessible to traffic and wildlife.

Landfill A3-1 (CAS 03-08-001-A301): Landfill A3-1 is located at the north end of the CAU and is the largest of the landfill cells. The seven above-grade concrete monuments that demarcate the landfill cell and the cover were examined. All monuments, attached signs, and survey pins capping the monuments were legible and in excellent condition. There was no evidence of cover subsidence, cracking, erosion, or animal burrows. Vegetation was present on the cover, but sparse compared to surrounding undisturbed areas.

Landfill A3-2 (CAS 03-08-002-A302): Landfill A3-2 is located due south of Landfill A3-1. Four above-grade monuments and the landfill cover were examined. All monuments, attached signs, and survey pins capping the monuments were legible and in excellent condition. There was no evidence of subsidence, cracking, or erosion of the landfill cover. No animal burrows were present on the cover or around the base of the monuments. Vegetation was present and healthy but sparse compared to the surrounding undisturbed area. The cover and monuments were in overall excellent condition.

Landfill A3-3 (CAS 03-08-002-A303): Landfill A3-3 straddles the western fence line of the Sandia National Laboratories Area 3 Compound, with parts of the landfill outside the fence and parts inside the fence. Three above-grade monuments marking the western edge of the landfill cell located outside the fence were examined. The three above-grade monuments, attached signs, and brass survey pins were legible and in excellent condition. Three at-grade brass marker pins demarcating the eastern edge of the landfill (installed during closure activities) were located just inside the Area 3 fence line. All were easily located, clearly visible, and legible. The area outside the fence was covered by sparse vegetation. The area inside the fence is heavily trafficked and bare of vegetation.

A small third waste cell (approximately 3 by 3 meters [ 10 by 10 feet]), located immediately east of the dirt access road to the Bechtel Nevada Field Office (Building 03-78), was inspected. The cell is in a heavily trafficked area and the three at-grade brass makers, placed during site closure, were not located. As was the case for the 2000 site inspection, road grading has covered these pins. The covers over each of the three cells were in excellent shape with no signs of cracking, subsidence, or erosion.

Landfill A3-4 (CAS 03-08-002-A304): Landfill A3-4 is located just south of Dykes Drive at the south end of the CAU. Five above-grade monuments and one at-grade brass marker pin were located. All monuments, the marker, attached signs, and survey pins were legible and in good condition. The cover was in excellent shape with no signs of cracking, subsidence, or erosion. Vegetation is sparse but well established on the cover.

Landfill A3-5 (CAS 03-08-002-A305): Landfill A3-5 is located west of Moody Avenue inside a fenced area south of the Air Force First-Aid Station. All four above-grade monuments with attached warning signs and brass survey pins were located. All monuments, attached signs, and 
survey pins were legible and in excellent condition. The area was vegetated with Russian Thistle and sparse grasses. The cover was in excellent condition with no evidence of subsidence, cracking, or erosion.

Landfill A3-6 (CAS 03-08-002-A306): Landfill A3-6 is located immediately west of and outside the fence line of the Area 3 Compound. All four above-grade monuments with attached warning signs and brass survey pins were located. All monuments, signs, and pins were in excellent condition. The area is sparsely vegetated with native species. No evidence of cover subsidence or erosion was observed. The overall condition of the cover was excellent.

Landfill A3-8 (CAS 03-08-002-A308): Landfill A3-8 is located southwest of the Area 3 Compound in the area of storage box cars (see photographs 11 and 19). This unit was closed by placing four at-grade brass marker pins at the corners of the unit. The southwest at-grade marker was located and was in excellent condition. The inspection was unable to locate the other three markers due to regrading of the dirt access road running through the area. The markers have been buried with soil from the regrading work. The area is not vegetated due to heavy traffic. There was no evidence of subsidence or erosion to the cover. The overall condition of the landfill cover is excellent.

\subsection{November 6, 2001 Inspection}

The second inspection of CUA 424 was conducted on November 6, 2001.

Landfill A3-1 (CAS 03-08-001-A301): All seven above-grade monuments were located. All monuments, attached warning signs, and stamped brass survey pins were in excellent condition. Minor animal burrows were present at the base of five monuments. Vegetation on the cover is sparse compared to surrounding undisturbed areas, but appears healthy and well established. No evidence of subsidence, cracking, or erosion of the landfill cover was observed. The overall condition of the landfill cover is excellent.

Landfill A3-2 (CAS 03-08-002-A302): All four above-grade monuments were located. All monuments, attached warning signs, and stamped brass survey pins were in excellent condition. Sparse vegetation is present on the cover. No evidence of cover subsidence, cracking, or erosion was observed. The overall condition of the cover is excellent.

Landfill A3-3 (CAS 03-08-002-A303): All three above-grade monuments and three at-grade brass marker pins marking the west cells of the landfill were located. All monuments, marker pins, attached warning signs, and stamped brass survey pins were in excellent condition. Vegetation outside the Area 3 fence appeared healthy and well established, while the area inside the fence is not vegetated due to traffic. Three at-grade brass marker pins placed to mark the perimeter of a small landfill cell located directly east of the area access road, were not located. These markers have been covered with soil from recent road maintenance activities. The overall condition of the landfill cover is excellent. 
Landfill A3-4 (CAS 03-08-002-A304): All five above-grade monuments were located and inspected. The one at-grade brass marker pin was not located due to grading activity; it has been covered with soil. All monuments, attached warning signs, and survey pins were in excellent condition. Vegetation is sparse compared to adjacent undisturbed areas, but healthy and well established. No evidence of cover subsidence, cracking, or erosion was observed. The overall condition of Landfill A3-4 cover is excellent.

Landfill A3-5 (CAS 03-08-002-A305): All four above-grade monuments were located. All monuments, attached warning signs, and survey pins were in excellent condition. The cover area is vegetated by Russian Thistle. No evidence of cover subsidence, cracking, or erosion was observed. The overall condition of the landfill cover is excellent.

Landfill A3-6 (CAS 03-08-002-A306): All four above-grade monuments were located. All monuments, attached warning signs, and survey pins were in excellent condition. Vegetation on the landfill is healthy and well established. No signs of cover subsidence, cracking, or erosion were observed. The overall condition of the landfill cover is excellent.

Landfill A3-8 (CAS 03-08-002-A308): One of four at-grade brass marking pins was located at the southeast corner of the landfill. The three remaining at-grade marker pins were not visually located. They are in an area of high traffic use and have been covered with soil from road maintenance activities. The overall condition of the landfill cover is excellent with no evidence of subsidence, cracking, or erosion.

\subsection{RECOMMENDATIONS AND CONCLUSIONS}

The condition of the seven landfill units is excellent. All above-grade monuments were in excellent condition. The surface monuments that were located (three at A3-3 and one at A3-8) were in excellent condition. All warning signs and survey pins are legible and in good condition. Run-off is being properly diverted away from the landfill units and there is no evidence of drainage or erosion to any of the landfill units. The at-grade surface monuments that were not located (three at A3-3, one at A3-4, and three at A3-8) due to traffic and road maintenance work will be located during the 2002 site inspections. These monuments will be located by a survey crew from the site as-builts presented in the approved Closure Report (DOE/NV-283, July 1999) and re-installed as necessary. No modifications or repairs to the landfill cell covers, or changes in the frequency of site inspections, are recommended at this time. 
Post-Closure Inspection Report

CAU No. 424

Area 3 Landfill Complexes

Revision: 0

Date: January 24, 2002

ATTACHMENT A

INSPECTION CHECKLISTS 
Post-Ciosure inspection Report CAU vo 424

Ared 3 Landill Lumplexes

Revision: 0

Date: January 24, 2002

THIS PAGE INTENTIONALLY LEFT BLANK 
CAU 424: AREA 3 LANDFILL COMPLEX, POST-CLOSURE INSPECTION CHECKLIST

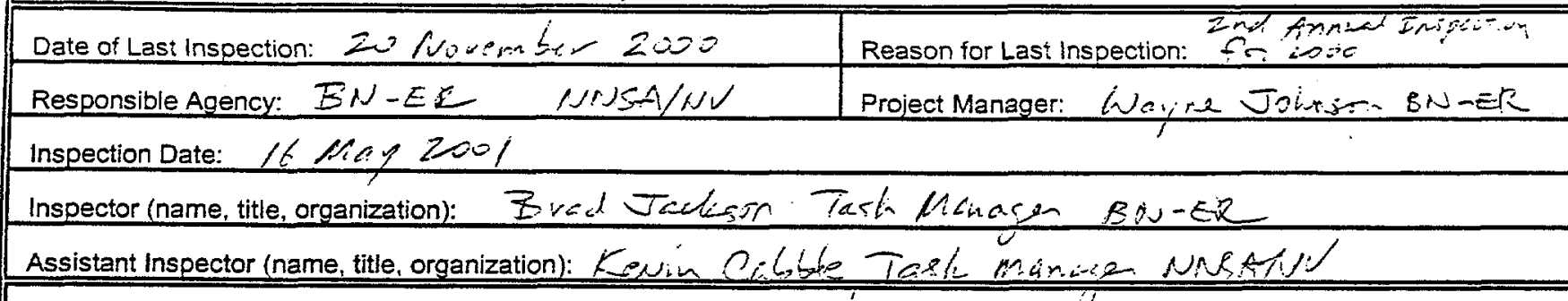

\section{A. GENERAL INSTRUCTIONS}

1. All checklist items must be completed and detailed comments made to document the results of the site inspection. The completed checklist is part of the field record of the inspection. Additional pages should be used as necessary to ensure that a complete record is made. Attach the additional pages and number all pages upon completion of the inspection.

2. Any checklist line item marked by an inspector in a SHADED BOX, must be fully explained or an appropriate reference to previous reports provided. The purpose of this requirement is to provide a written explanation of inspector observations and the inspector's rationale for conclusions and recommendations. Explanations are to be placed on additional attachments and cross-referenced appropriately. Explanations, in addition to narrative, will take the form of sketches, measurements, annotated site maps.

3. The site inspection is a walking inspection of the entire site including the perimeter and sufficient transects to be able to inspect the entire surface and all features specifically described in this checklist.

4. A standard set of color $35 \mathrm{~mm}$ photographs (or equivalent) is required. In addition, all anomalous features or new features (such as changes in adjacent area land use) are to be photographed. A photo log entry will be made for each photograph taken.

5. This unit will be inspected biannually with formal reporting to the Nevada Division of Environmental Protection to be done annually. The annual report will include an executive summary, this inspection checklist with field notes and photo log attached, and recommendations and conclusions.

\begin{tabular}{|c|c|c|c|}
\hline B. PREPARATION (To be completed prior to site visit) & YES & NO & EXPLANATION \\
\hline 1. Site as-built plans and site base map reviewed. & & & \\
\hline \\
\hline $\begin{array}{l}\text { a. Were anomalies or trends detected on previous } \\
\text { inspections? }\end{array}$ & & & \\
\hline b. Was maintenance performed? & & & \\
\hline \multirow{3}{*}{$\begin{array}{l}\text { 3. Site maintenance and repair records reviewed. } \\
\text { a. Has site repair resulted in a change from as-built } \\
\text { conditions? } \\
\text { b. Are revised as-builts available that reflect repair changes? }\end{array}$} & & & $N / A$ \\
\hline & & & $N / A$ \\
\hline & & $\checkmark$ & $n / A$ \\
\hline C. SITE INSPECTION (TO be completed during inspection) & YES & NO & EXPLANATION \\
\hline
\end{tabular}

1. Adjacent off-site features within watershed areas.

a. Have there been any changes in use of adjacent area?

b. Are there any new roads or trails?

c. Has there been a change in the position of nearby washes?

d. Has there been lateral excursion or erosion/deposition of nearby washes?

e. Are there new drainage channels?

f. Change in surrounding vegetation?

\begin{tabular}{|c|c|c|}
\hline & 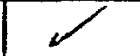 & \\
\hline & & \\
\hline & 2 & \\
\hline & 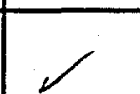 & \\
\hline & $\angle$ & \\
\hline & $\nearrow$ & \\
\hline
\end{tabular}

2. Security fence, signs.

a. Displacement of fences, site markers, boundary markers, or monuments?

b. Have any signs been damaged or removed? (Number of signs replaced: $\phi^{3}$

c. Were gates locked?

\begin{tabular}{|l|l|l|}
\hline & \multicolumn{1}{|l|}{} \\
\hline & $/$ & \\
\hline & $\nu$ & N/S No gutes at CAM 424 \\
\hline
\end{tabular}


CAU 424: AREA 3 LANDFILL COMPLEX, POST-CLOSURE INSPECTION CHECKLIST

3. Waste Unit cover.

a. Is there evidence of settling?

b. Is there cracking?

c. Is there evidence of erosion around the cap (wind or water)?

d. Is there evidence of animal burrowing?

e. Have the site markers been disturbed by man or natural processes?

f. Is the vegetation on the cover?

g. Do natural processes threaten to integrity of any cover or site marker?

h. Other?

\begin{tabular}{|c|c|c|}
\hline YES & NO & EXPLANATION \\
\hline & & \\
\hline & & \\
\hline$\nu$ & & minor biniowim et $43-4$ \\
\hline & & $v$ \\
\hline & 4 & 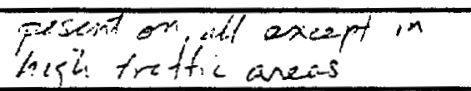 \\
\hline & & Niti \\
\hline
\end{tabular}

4. Photo Documentation

a. Has a photo log been prepared?

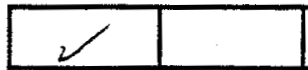

c. Number of photos exposed ( 20$)$

\section{FIELD CONCLUSIONS}

1. Is there an imminent hazard to the integrity of the unit? (Immediate report required)

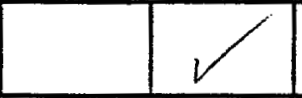

Person/Agency to whom report made:

2. Are more frequent inspections required?

3. Are existing maintenance/repair actions satisfactory?

4. Is other maintenance/repair necessary?

5. Is current status/condition of vegetative cover satisfactory?

6. Rationale for field conclusions:

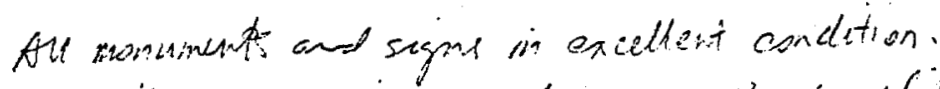

$$
\begin{aligned}
& \text { No evidence of sibsidence at arry } 8 \text { the lartifill eults. }
\end{aligned}
$$

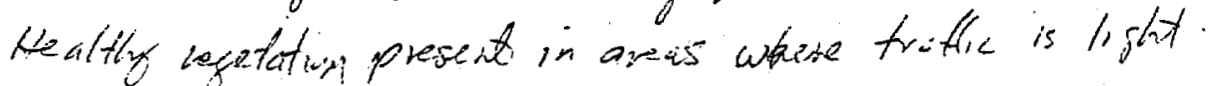

\section{E. CERTIFICATION}

I have conducted an inspection of the Area 3 Landfill Complex, CAU 424, at the TTR in accordance with the Post-Closure Inspection Plan (see Closure Report) as recorded on this checklist, attached sheets, field notes, photo logs, and photographs.

Chief Inspector's Signature:

Printed Name:

Bred Jackion

Titie: Task Mansiz

16 nists 2001 
CAU 424: AREA 3 LANDFILL COMPLEX, POST-CLOSURE INSPECTION CHECKLIST

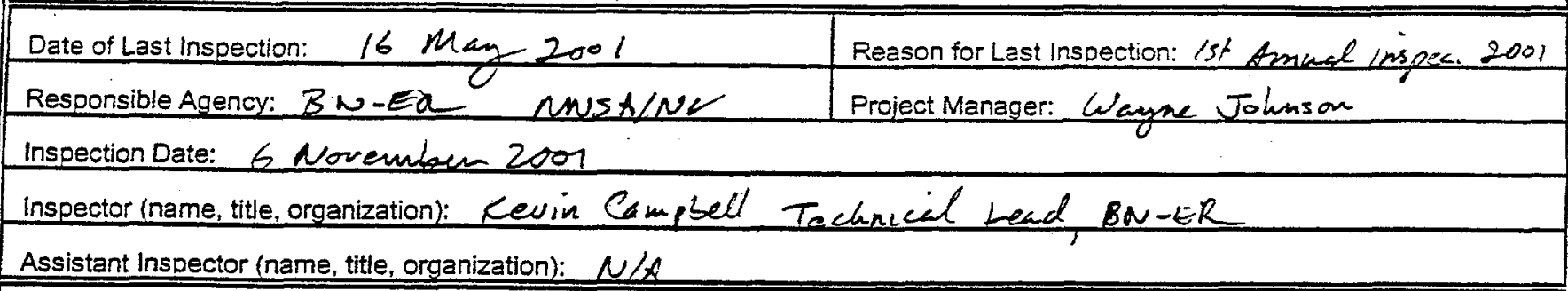

\section{A. GENERAL INSTRUCTIONS}

1. All checklist items must be completed and detailed comments made to document the results of the site inspection. The completed checklist is part of the field record of the inspection. Additional pages should be used as necessary to ensure that a complete record is made. Attach the additional pages and number all pages upon completion of the inspection.

2. Any checklist line item marked by an inspector in a SHADED BOX, must be fully explained or an appropriate reference to previous reports provided. The purpose of this requirement is to provide a written explanation of inspector observations and the inspector's rationale for conclusions and recommendations. Explanations are to be placed on additional attachments and cross-referenced appropriately. Explanations, in addition to narrative, will take the form of sketches, measurements, annotated site maps.

3. The site inspection is a walking inspection of the entire site including the perimeter and sufficient transects to be able to inspect the entire surface and all features specifically described in this checklist.

4. A standard set of color $35 \mathrm{~mm}$ photographs (or equivalent) is required. In addition, all anomalous features or new features (such as changes in adjacent area land use) are to be photographed. A photo log entry will be made for each photograph taken.

5. This unit will be inspected biannually with formal reporting to the Nevada Division of Environmental Protection to be done annually. The annual report will include an executive summary, this inspection checklist with field notes and photo log attached, and recommendations and conclusions.

\begin{tabular}{|c|c|c|c|}
\hline B. PREPARATION (To be completed prior to site visit) & YES & NO & EXPLANATION \\
\hline 1. Site as-built plans and site base map reviewed. & & & \\
\hline \multicolumn{4}{|l|}{ 2. Previous inspection reports reviewed. } \\
\hline $\begin{array}{l}\text { a. Were anomalies or trends detected on previous } \\
\text { inspections? }\end{array}$ & & & \\
\hline b. Was maintenance performed? & & & \\
\hline \multirow{3}{*}{$\begin{array}{l}\text { 3. Site maintenance and repair records reviewed. } \\
\text { a. Has site repair resulted in a change from as-built } \\
\text { conditions? }\end{array}$} & & & $N / A$ \\
\hline & & & $N / A$ \\
\hline & & & $N A$ \\
\hline C. SITE INSPECTION (To be completed during inspection) & YES & NO & EXPLANATION \\
\hline
\end{tabular}

1. Adjacent off-site features within watershed areas.

a. Have there been any changes in use of adjacent area?

b. Are there any new roads or trails?

c. Has there been a change in the position of nearby washes?

d. Has there been lateral excursion or erosion/deposition of nearby washes?

e. Are there new drainage channels?

f. Change in surrounding vegetation?

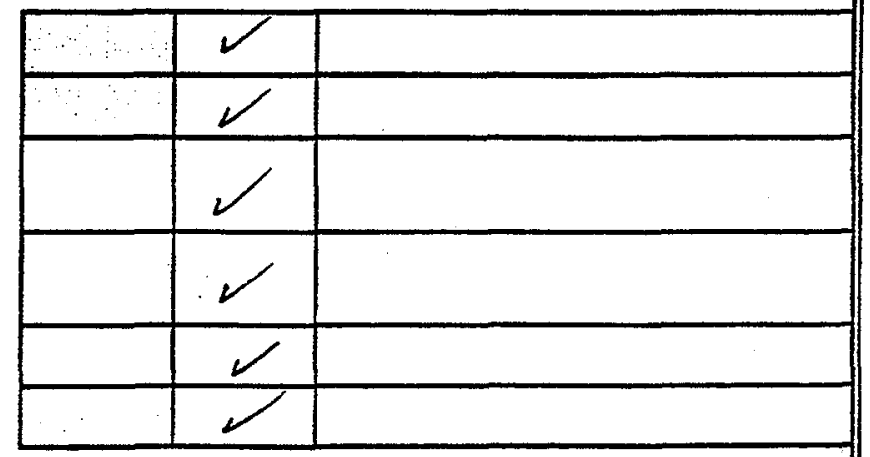

2. Security fence, signs.

a. Displacement of fences, site markers, boundary markers, or monuments?

b. Have any signs been damaged or removed? (Number of signs replaced: (D)

c. Were gates locked?

\begin{tabular}{|l|l|l|}
\hline & \multicolumn{1}{|l|}{} \\
\hline & \multicolumn{1}{|l|}{} \\
\hline & & N/A No gates \\
\hline
\end{tabular}




\section{CAU 424: AREA 3 LANDFILL COMPLEX, POST-CLOSURE INSPECTION CHECKLIST}

3. Waste Unit cover.

a. Is there evidence of settling?

b. Is there cracking?

c. Is there evidence of erosion around the cap (wind or water)?

d. Is there evidence of animal burrowing?

e. Have the site markers been disturbed by man or natural processes?

f. Is the vegetation on the cover?

g. Do natural processes threaten to integrity of any cover or site marker?

h. Other?

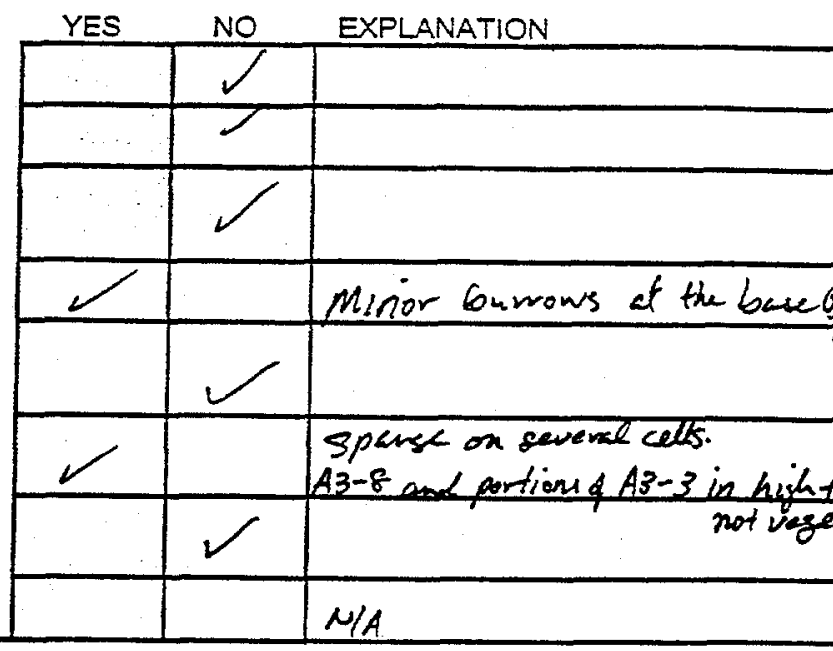

4. Photo Documentation

a. Has a photo log been prepared?

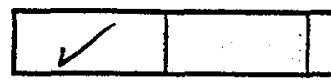

c. Number of photos exposed $(10$

\section{FIELD CONCLUSIONS}

1. Is there an imminent hazard to the integrity of the unit? (Immediate report required)

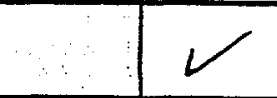

Person/Agency to whom report made:

\section{Are more frequent inspections required?}

3. Are existing maintenance/repair actions satisfactory?

4. Is other maintenance/repair necessary?

5. Is current status/condition of vegetative cover satisfactory?

6. Rationale for field conclusions: AU signs anl above guade monument in exectlent conclitery

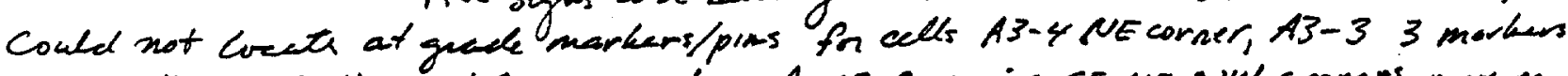

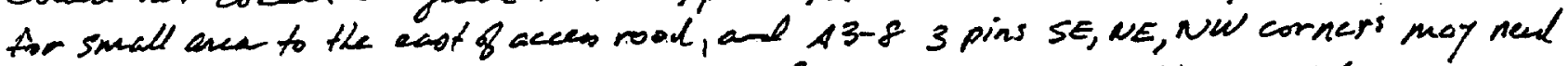
to hwe survey relocate corners and place ferrows morkers detectelle by metal datectors in 1

\section{E. CERTIFICATION}

I have conducted an inspection of the Area 3 Landfill Complex, CAU 424, at the TRR in accordance with the Post-Closure Inspection Plan (see Closure Report) as recorded on this checklist, attached sheets, field notes, photo logs, and photographs.

Inspector's Signature:

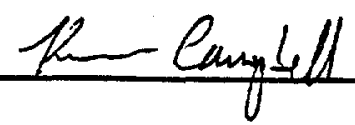
Printed Name: Kevin Camplall

Title: Techniral Lend BNER Date: 6.100.rember 2001 
Post-Closure inspection Report C.AU No. 424

Area 3 Landfill Complexes

Revision: 0

Date: January 24. 2002

\section{ATTACHMENT B}

\section{FIELD NOTES}


Post-Closure Inspection Report CAU No. 424

Area 3 Landill Compleses

Revision: 0

Date: January 24, 2002

THIS PAGE INTENTIONALLY LEFT BLANK 


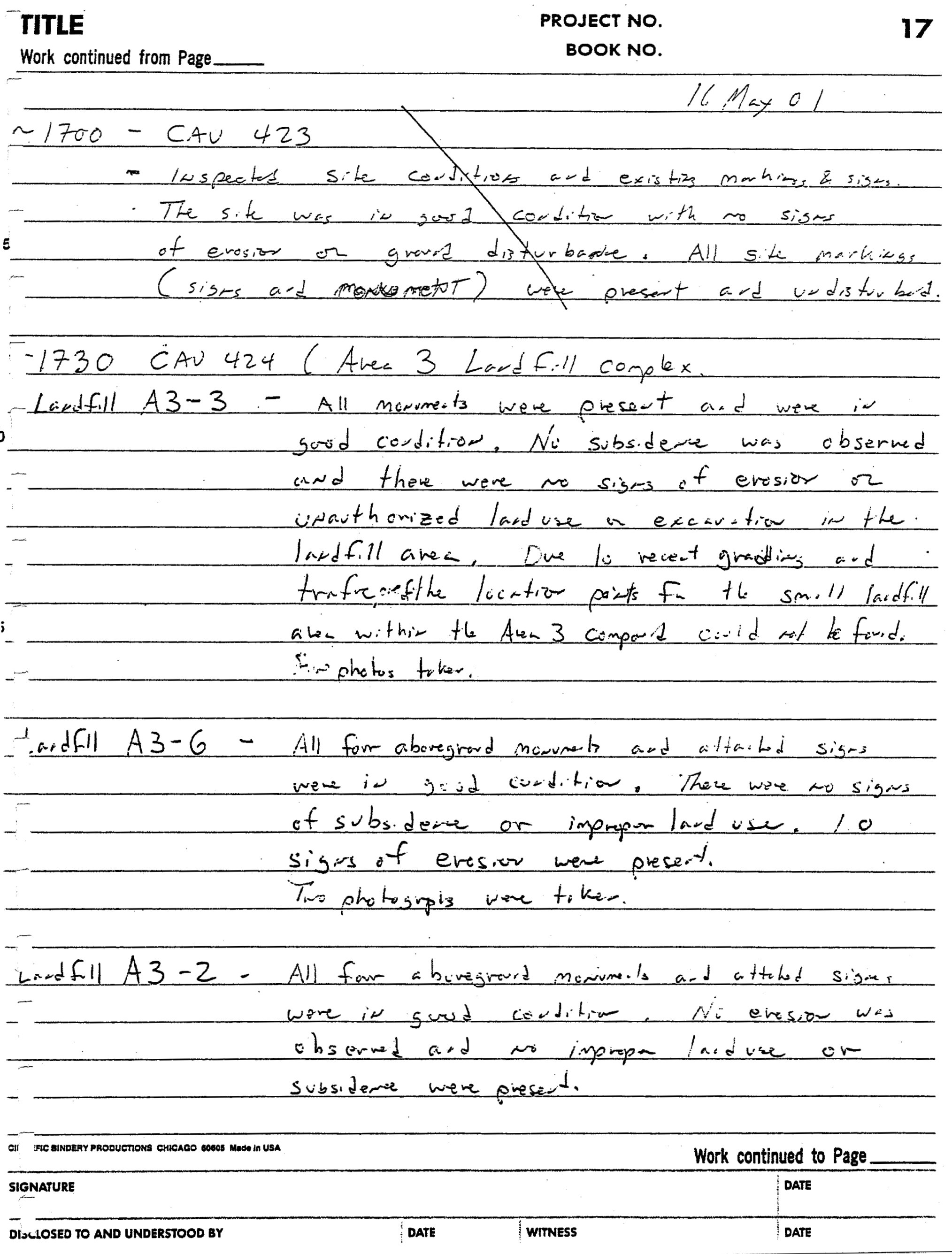


18 TITLE

Work continued from Page
PROJECT NO.

BOOK NO.

$161 \%, 01$

CAN $424-A-3$ lardfll cintix

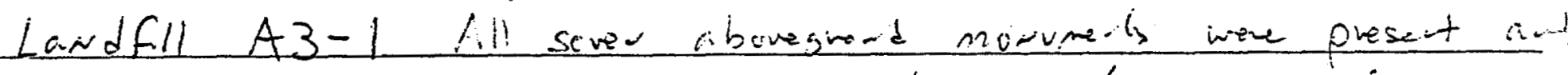
were in sood coplition. No evidere if ewsice

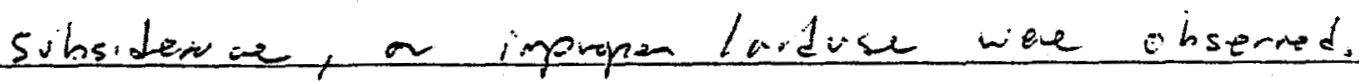
Thine stotis were tiker

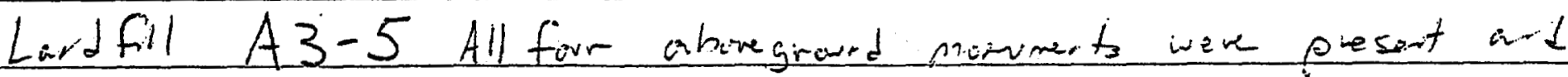
were in scrid covdition. Ni evidere t evesio or imprope land us were obserwd.

10 Tiriplotis wo tiker

Laudfill A3-8 Nore of the laodfoll marker pads wee locited due to trafe and veiert gradion ir the ave The locrtion of the two landfll cells were in 15 goid corditior aud wo siges of subsideme or inprope laudrse. wo Thire photos were tilker.

Ladfll A3-4 Loceted fow abovegrowd mowreb and ore 20 at jore de mavkinart. Morvmets ware ir joid corditions ard signs were ledgorbl. The wae no sises ef subsiden, erosior, on impirp - landice. Tiro phitus we tolu

${ }^{25}$ Lardfll A3.7 No monrmerb presert ot s.te: No sigars of evesiar, subsidare, a impompon lardre wen observi?. One phito wos tive

SCIENTTFIC GINDERY PAOOUCTIONS GHICACO GOBOS Made in USA

Work continued to Page SIGNATURE

DATE

DISCLOSED TO AND UNDERSTOOD BY

DATE

WITNESS

DATE 
22 TITLE

Work continued from Page 21
PROJECT NO.

BOOK NO.

Roller Counter Sewage Le poon (CAu404)

1223 Amir sit.

bates, fence, signs all in excellent condition.

Cover vegetation healthy and more dense than outside fere.

small borrows present at base of fence ling bach filled by banal

Numerous small moral burnous present inside fence bung fencing

is not buried as at other sites allowing eminals access under fencing

No burrows presententep of raised ar la

No evidence of erosion orr side slope

Drainage swill north of opec in excellent-concitron - no exponent envoi:

Reattached two sign with log rings

1300 Depart site

1310 Rollercoaster Rad Sate site (couy07)

Barbed wire fencing is good condition. No burn fencing plepresent.

Postings "Underground Radioactive Material" still up fth place

Vegetation inside fence very healthy.

Numerous small mama burrows present inside fenced area and on side slopes of cover.

${ }^{20}$ - No the to integinty of cover

All signs in good shape

326 Depart site

35 A3-4 site (CAM 423)

5 - All 5 abore-grade monuments in good condition

All attached signs in good condition

Vegetation mainly helogeten some native species all heed thy but sparse.

Many small mammal burrows present.

5T THE BENDERY PfHODUCTIONG CHICAGO 60605 Made in USA

SIGNATURE

Work continued to Page 23

I CLOSED TO AND UNDERSTOOD BY

DATE

WITNESS

DATE $1 / / 6 l 01$

otto 
TITLE

Work continued from Page 22
PROJECT NO.

BOOK NO.

23.

$A 3=3$ Veg hal thy

3 above gauche monument in excellewicondition 3 at grade monuments inside tres 3 fence in excellent condition All signs, marker pin in excellent condition

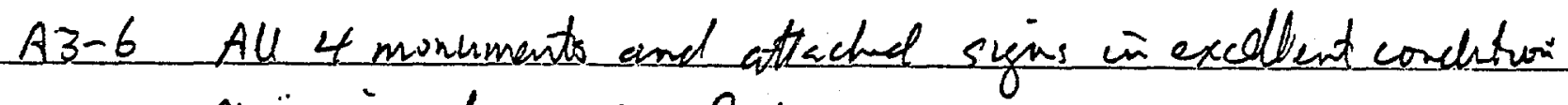
Ni" signs of excision future

Veg. healthy

A3-2 4 monuments s signs un excellent condutui Healthy vegetation.

No essoconal festive

${ }^{15}$ A3-1 se 7 monuments a signs in excellent condition.

Do evidence of subsidence vichy a erosion

Veg. healthy but spouse

A3-5 4 monuments signs in excellent shape

20 vegetation manly thistle.

A3-8 Could locate only 1 of 4 at grade monuments.

thigh traffic one.

630 Depart site for LV.

25

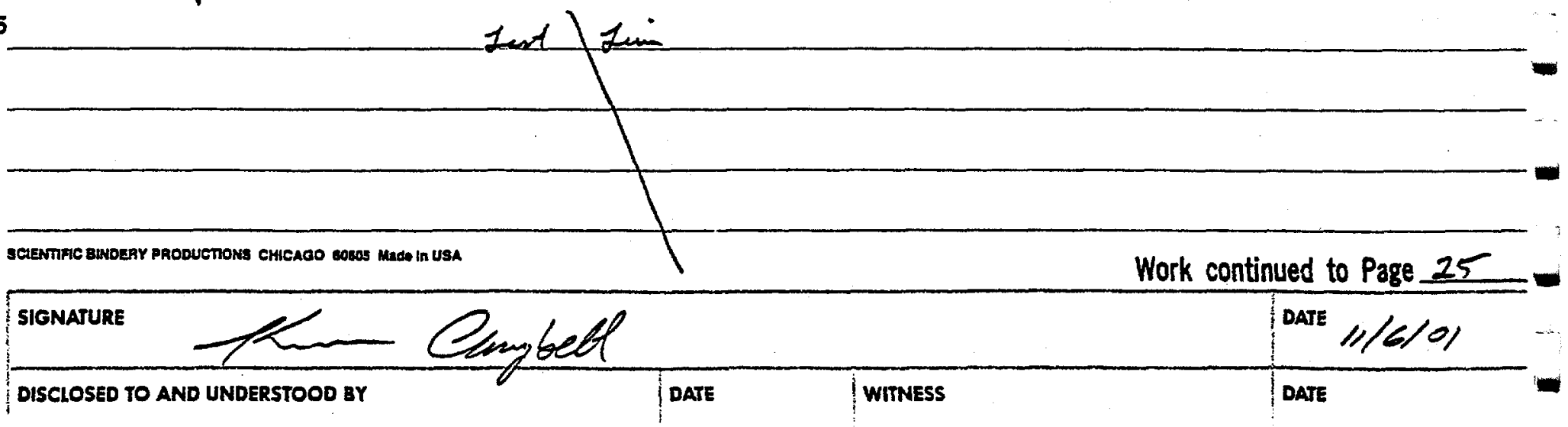


Post-Closure Inspection Report

CAU No. 424

Area 3 Landfill Complexes

Revision: 0

Date: January 24, 2002

\section{ATTACHMENT C}

\section{PHOTOGRAPH LOG AND PHOTOGRAPHS}


Post-Closure Inspection Report

CAL No. 424

Area 3 Landfill Complexes

Revision: 0

Date: January 24, 2002

THIS PAGE INTENTIONALLY LEFT BLANK

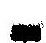




\section{PHOTOGRAPH LOG}

\begin{tabular}{|c|c|l||}
\hline $\begin{array}{c}\text { PHOTO } \\
\text { NUMBER }\end{array}$ & \multicolumn{1}{|c|}{ DATE } & \multicolumn{1}{|c|}{ DESCRIPTION } \\
\hline \hline 1 & $05 / 16 / 2001$ & View of Landfill A3-1 looking northeast from the southwest. \\
\hline 2 & $05 / 16 / 2001$ & View of Landfill A3-1 looking north from the south. \\
\hline 3 & $05 / 16 / 2001$ & View of Landfill A3-2 looking north from the south. \\
\hline 4 & $05 / 16 / 2001$ & View of Landfill A3-3 from outside Area 3 fence looking east. \\
\hline 5 & $05 / 16 / 2001$ & View of Landfill A3-3 from inside Area 3 fence looking north. \\
\hline 6 & $05 / 16 / 2001$ & View of Landfill A3-3 surface markers inside Area 3 fence. \\
\hline 7 & $05 / 16 / 2001$ & $\begin{array}{l}\text { View of Landfill A3-3 cell on east side of dirt access road. Cell } \\
\text { is located under machinery parked near car. Surface monuments } \\
\text { mark cell. }\end{array}$ \\
\hline 8 & $05 / 16 / 2001$ & View of Landfill A3-4 looking south from northwest cell corner. \\
\hline 9 & $05 / 16 / 2001$ & View of Landfill A3-5 looking west from Moody Ave. \\
\hline 10 & $05 / 16 / 2001$ & View of Landfill A3-6 looking north from south. \\
\hline 11 & $05 / 16 / 2001$ & $\begin{array}{l}\text { View of Landfill A3-8 looking north at boxcars. Surface } \\
\text { monuments mark cell corners. }\end{array}$ \\
\hline 12 & $11 / 06 / 2001$ & View of Landfill A3-1 looking north from south. \\
\hline 13 & $11 / 06 / 2001$ & View of Landfill A3-3 looking north from south. \\
\hline 14 & $11 / 06 / 2001$ & View of Landfill A3-2 looking north from south. \\
\hline 15 & $11 / 06 / 2001$ & View of Landfill A3-3 looking north from outside Area 3 fence. \\
\hline 16 & $11 / 06 / 2001$ & View of Landfill A3-4 looking south. \\
\hline 17 & $11 / 06 / 2001$ & View of Landfill A3-5 looking south. \\
\hline 18 & $11 / 06 / 2001$ & View of Landfill A3-6 looking north. \\
\hline 19 & $11 / 06 / 2001$ & $\begin{array}{l}\text { View of Landfill A3-8 looking north at boxcars. Surface } \\
\text { monuments mark cell corners. }\end{array}$ \\
\hline & & \\
\hline
\end{tabular}


Post-Closure Inspection Report

CAU No. 424

Area 3 Landfill Complexes

Revision: 0

Date: January 24, 2002

THIS PAGE INTENTIONALLY LEFT BLANK 


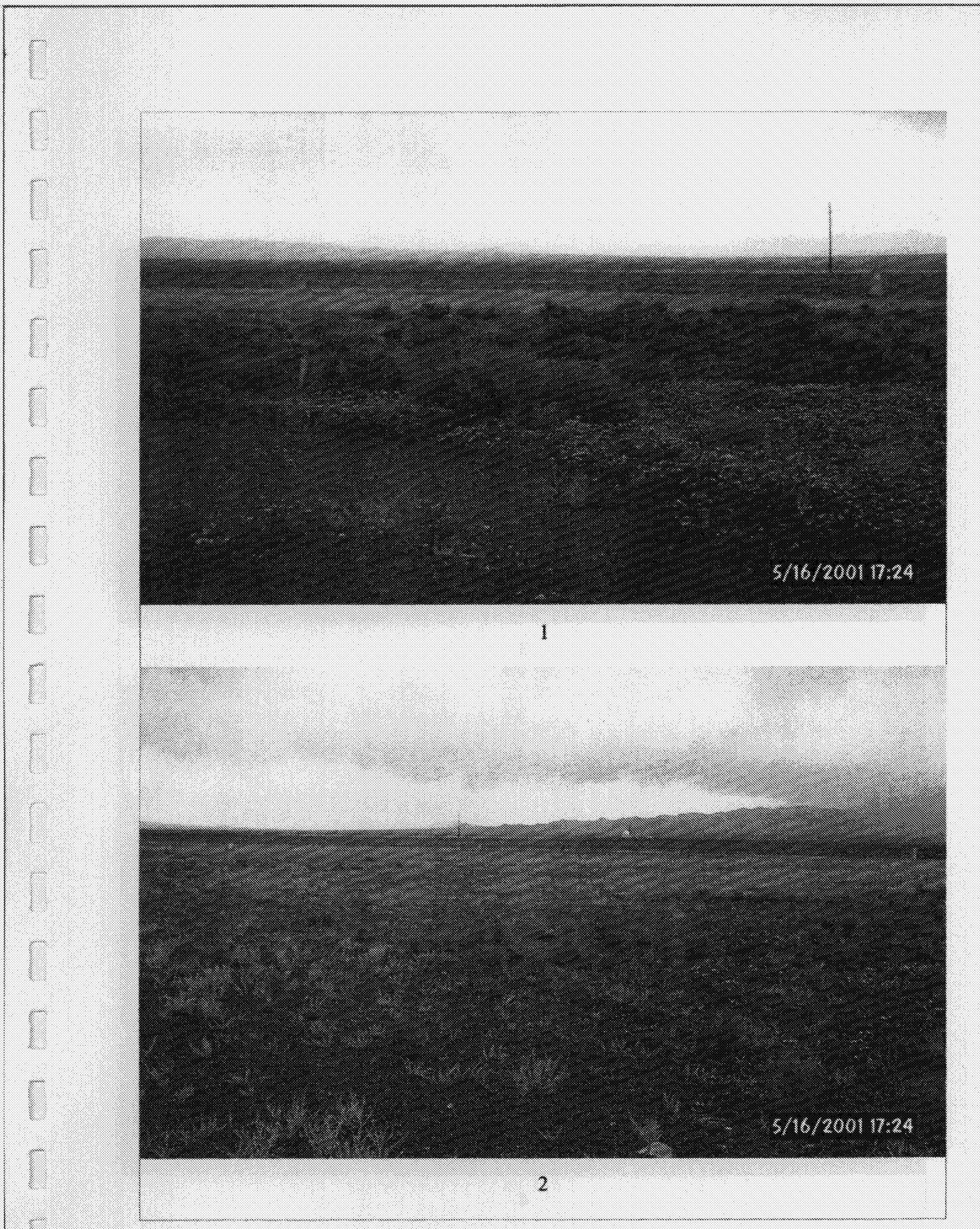




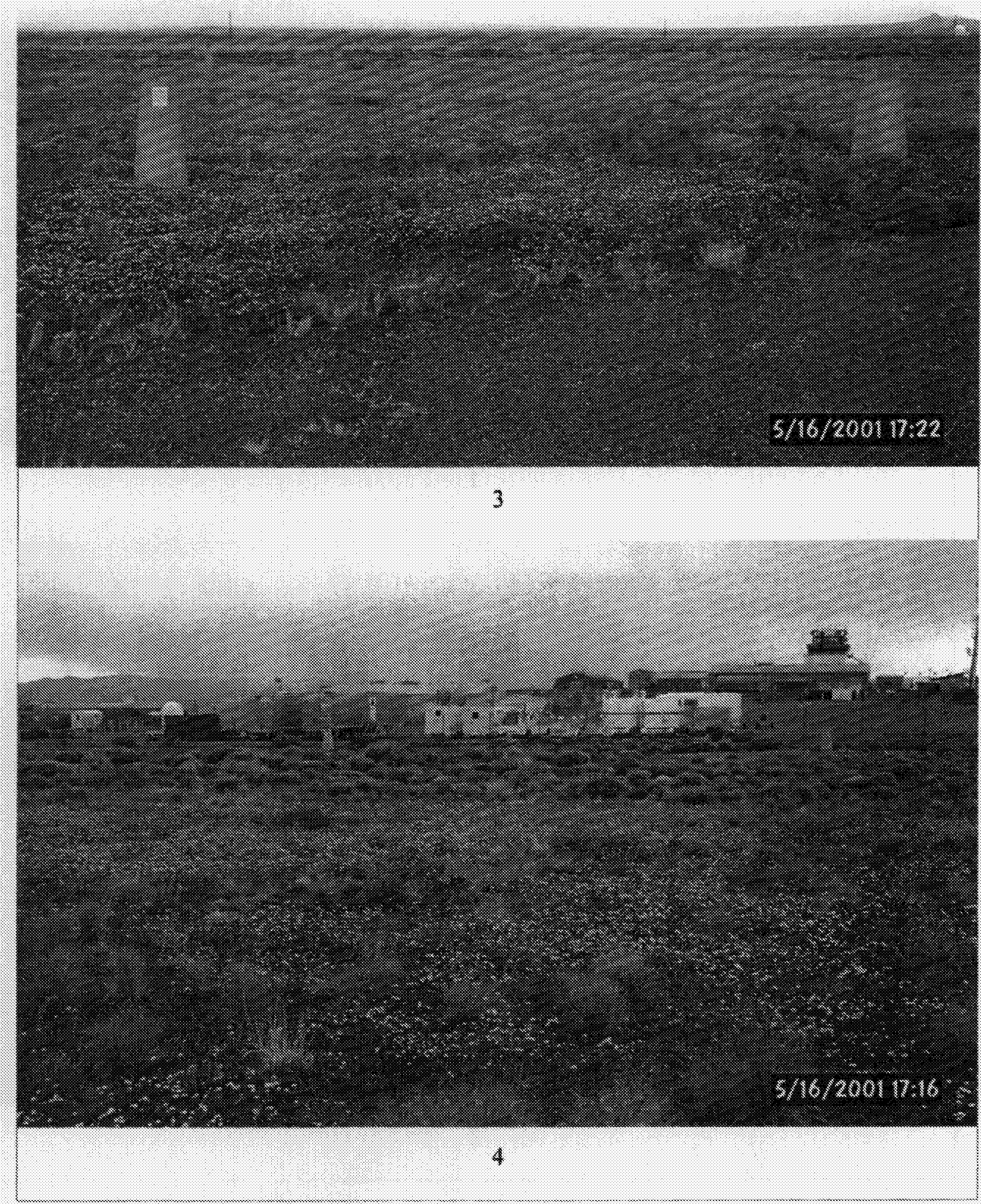




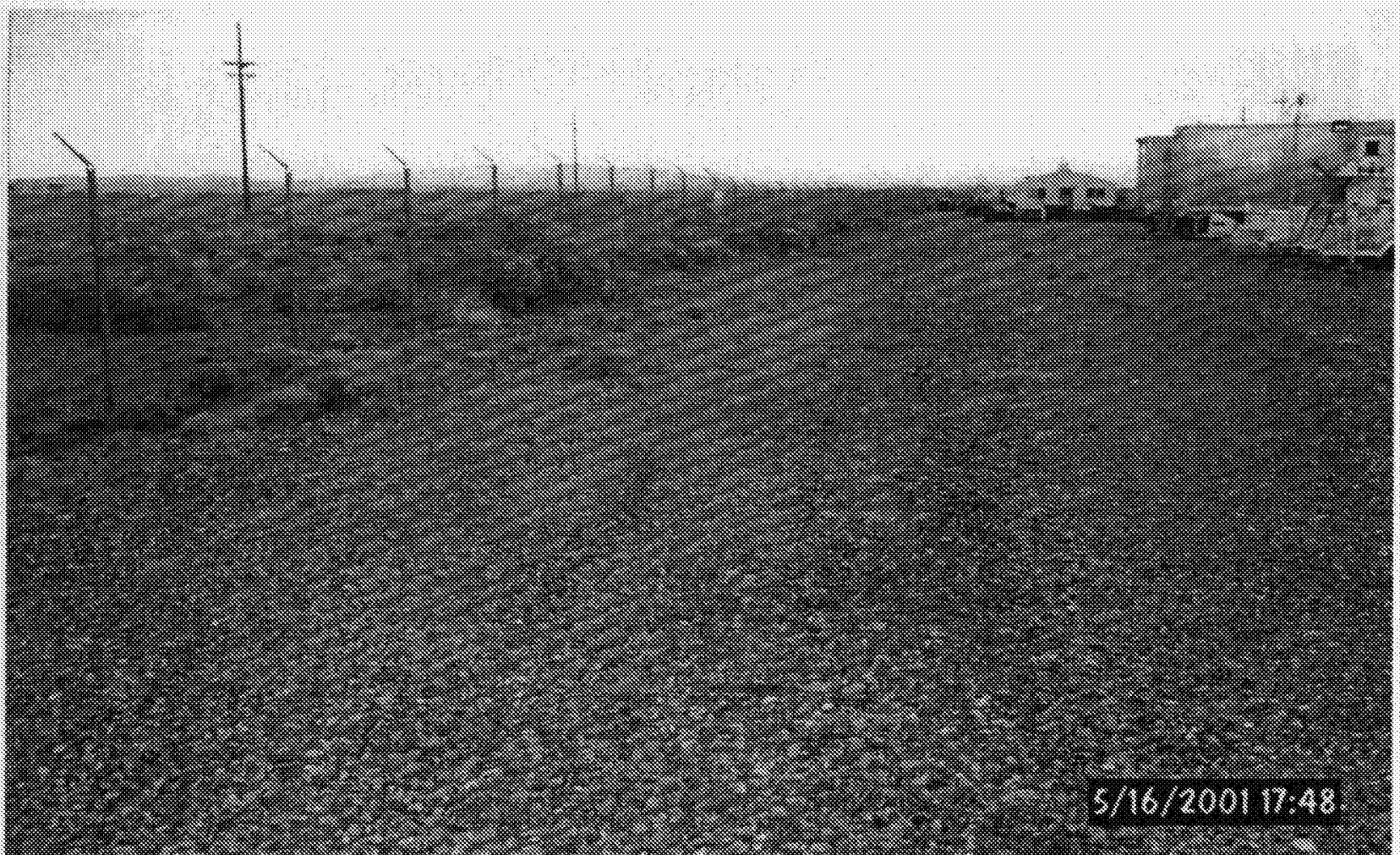

\section{5}

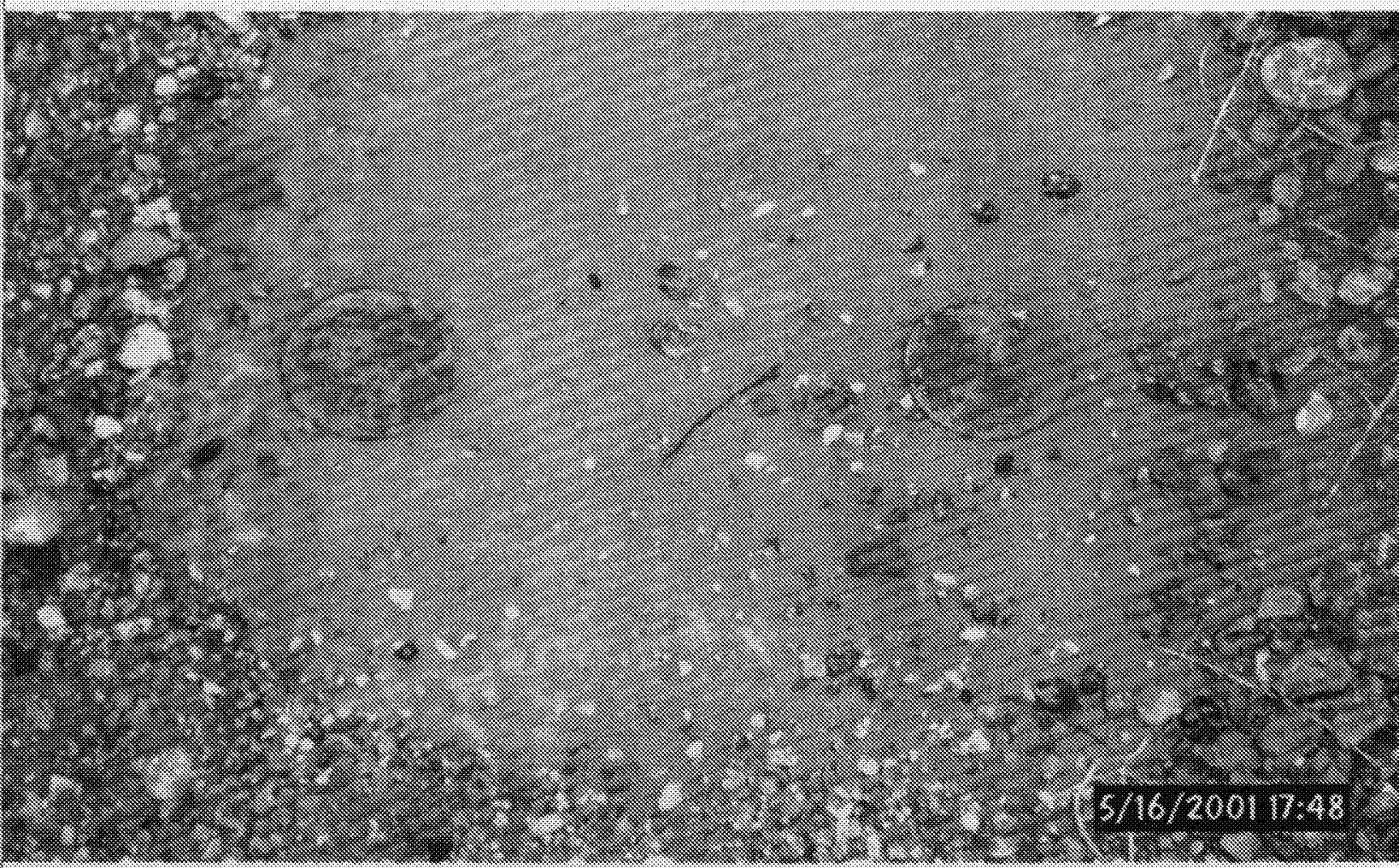




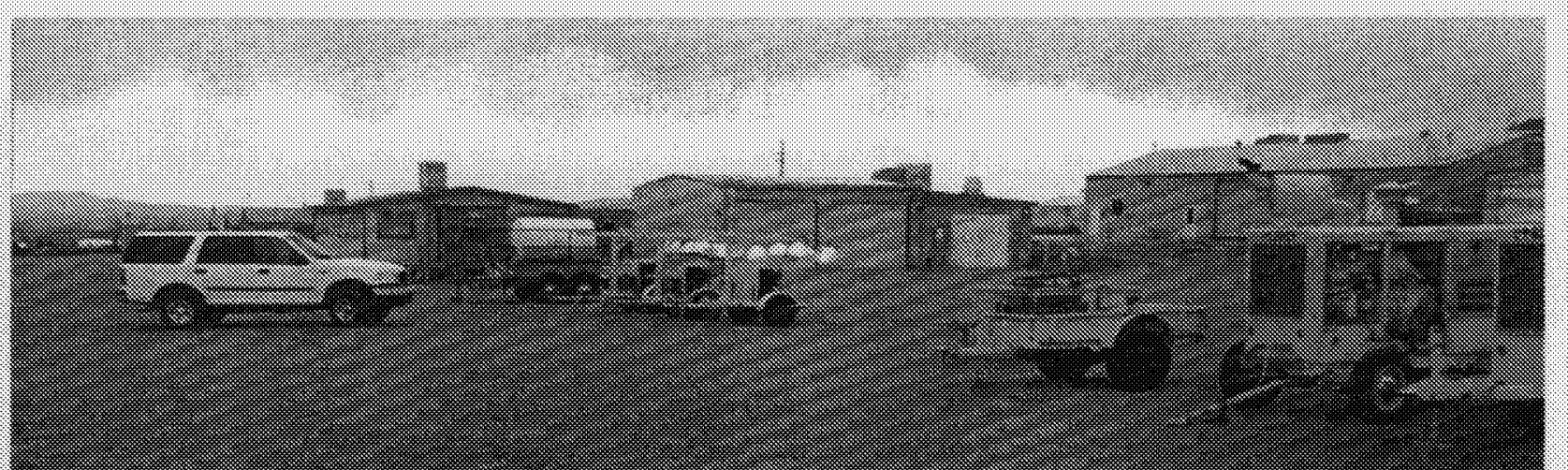

$5 / 16 / 2000177.11$ 

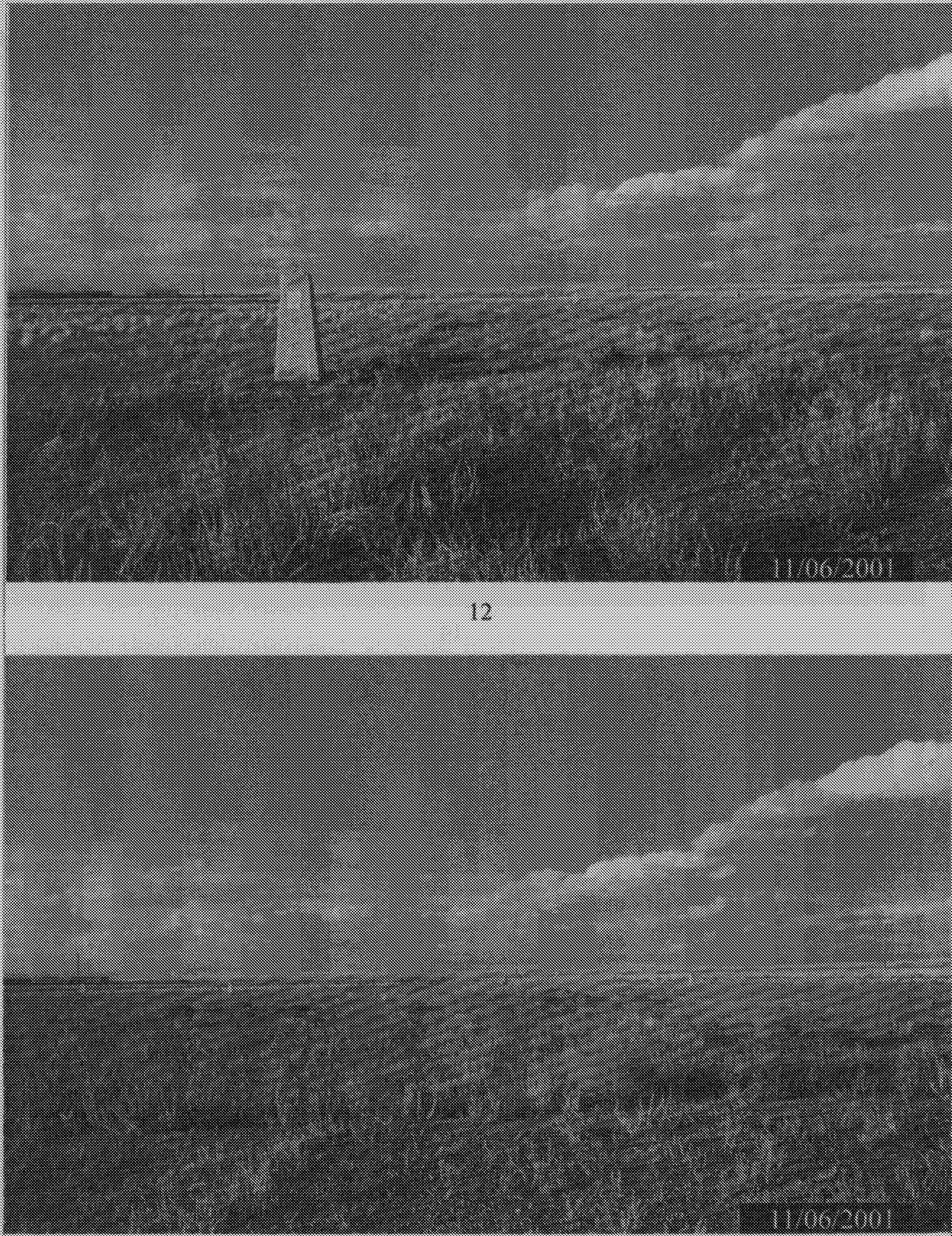


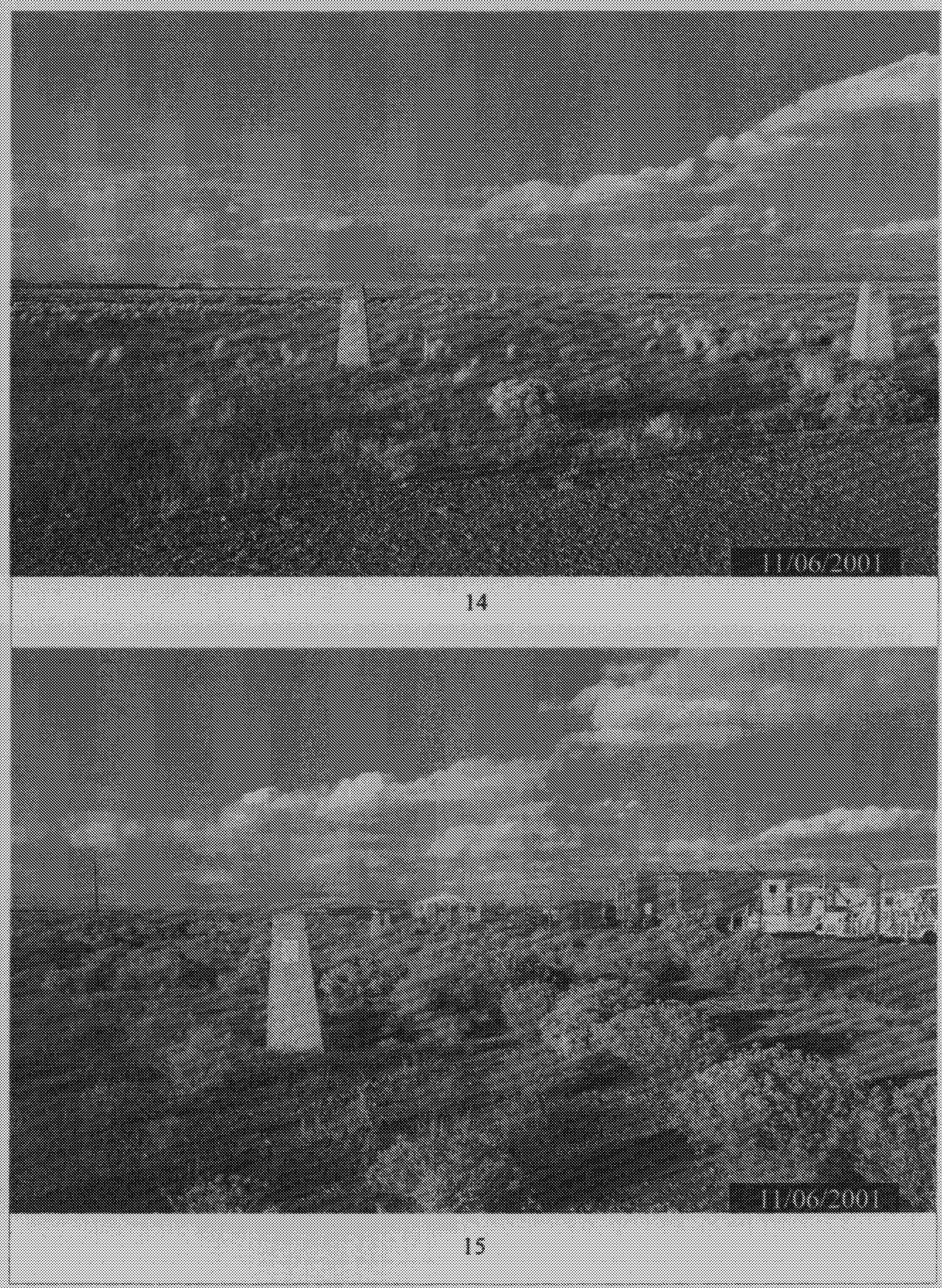




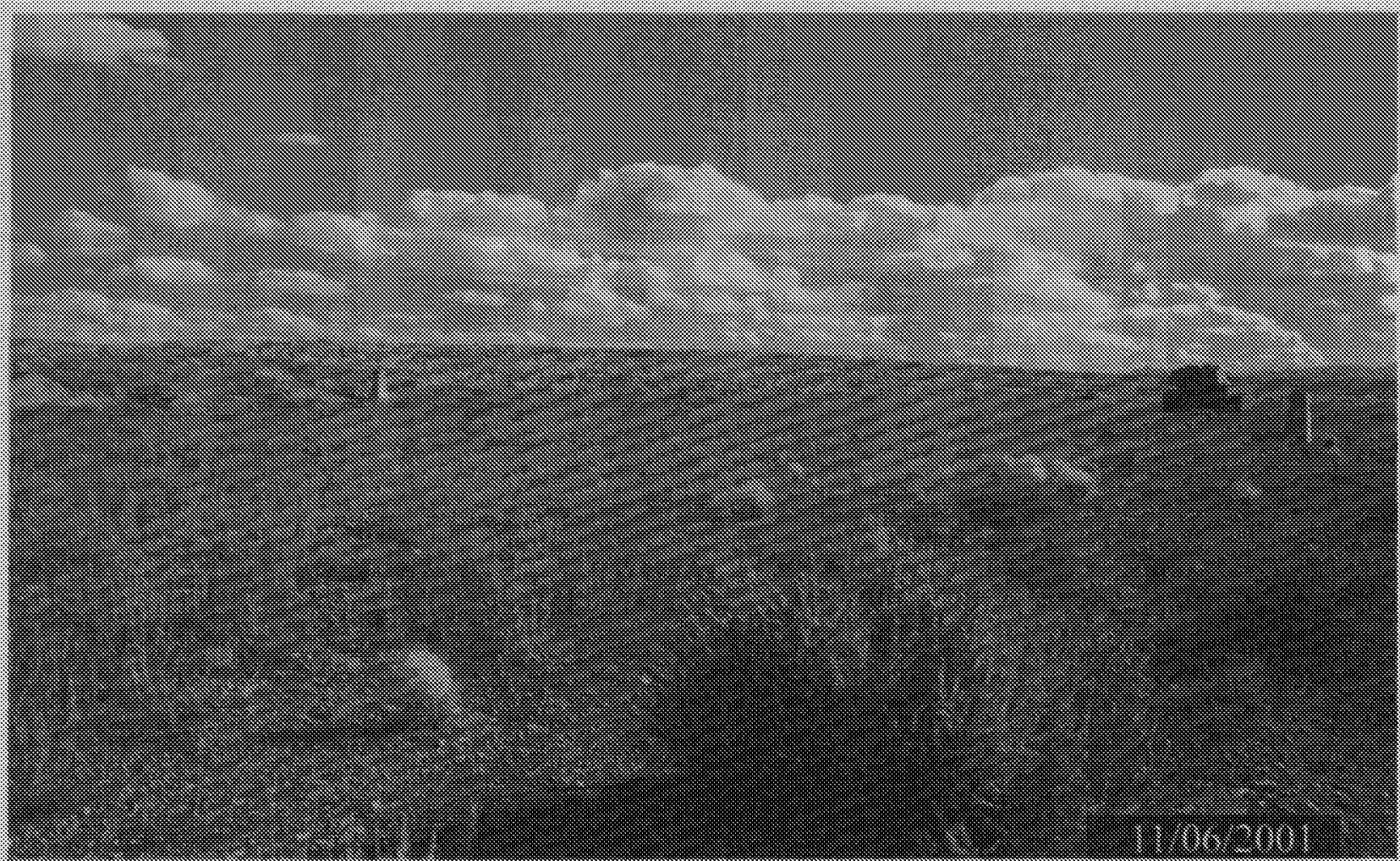

\section{6}




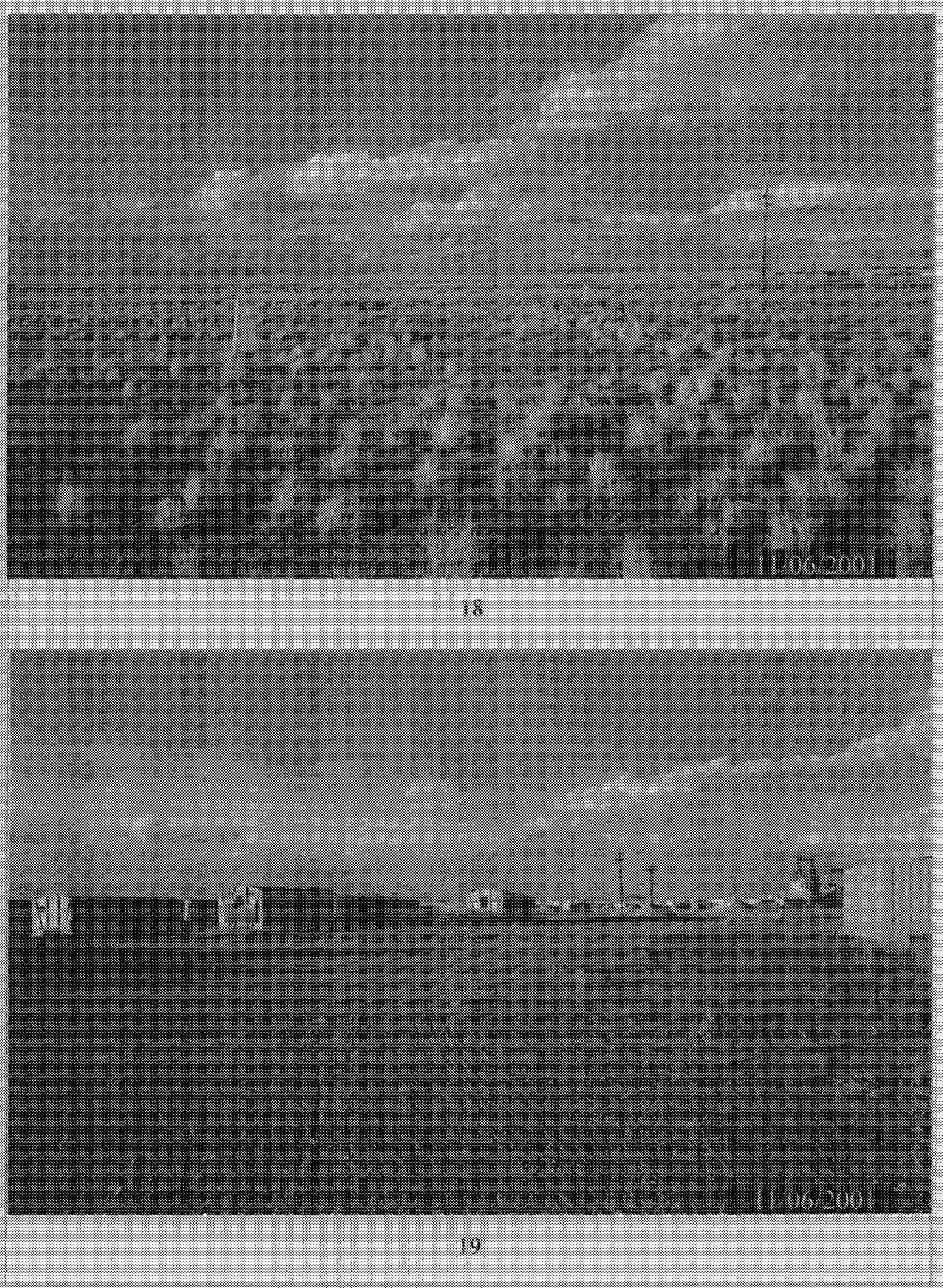


Post-Closure Inspection Report

CAU No. 424

Aтеa 3 Landfill Complexes

Revision: 0

Date: January 24, 2002

\section{DISTRIBUTION LIST}


Post-Closure Inspection Report

CAL No. 424

Area 3 Landill Complexes

Revision: 0

Date: January 24, 2002

THIS PAGE INTENTIONALLY LEFT BLANK 


\section{DISTRIBUTION LIST}

*Provide copy of initial distribution of Revision 0 ; remainder of list gets Revision 0 if approved without changes. The entire list receives Revision 1 , if issued.

\section{Nevada Department of Environmental Protection}

Paul Liebendorfer

2 (Controlled)* $^{*}$

Bureau of Federal Facilities

Division of Environmental Protection

333 W. Nye Lane, Room 138

Carson City, NV 89706-0866

Supervisor, Las Vegas Office

1 (Controlled)*

- Bureau of Federal Facilities

Division of Environmental Protection

555. E. Washington, Suite 4300

Las Vegas, NV 89010-1043

\section{U.S. Department of Energy}

Janet Appenzeller-Wing

1 (Uncontrolled)*

Project Manager

Environmental Restoration Division

U.S. Department of Energy

National Nuclear Security Administration

Nevada Operations Office

P.O. Box 98518 M/S 505

Las Vegas, NV 89193-8518

Kevin Cabble

1 (Uncontrolled)*

Environmental Restoration Division

U.S. Department of Energy

National Nuclear Security Administration

Nevada Operations Office

P.O. Box $98518 \mathrm{M} / \mathrm{S} 505$

Las Vegas, NV 89193-8518

Sabrina Lawrence

1 (Controlled)*

Environmental Restoration Division

U.S. Department of Energy

National Nuclear Security Administration

Nevada Operations Office

P.O. Box $98518 \mathrm{M} / \mathrm{S} 505$

Las Vegas, NV 89193-8518 


\section{DISTRIBUTION LIST (Continued)}

\section{U.S. Department of Energy (continued)}

U.S. Department of Energy

1 (electronic copy)

Office of Scientific and Technical Information

P.O. Box 62

Oak Ridge, TN 37831-0062

U.S. Department of Energy

National Nuclear Security Administration

1 (Controlled) \&

Nevada Operations Office

1 (Uncontrolled)

Public Reading Facility

P.O. Box $98521 \mathrm{M} / \mathrm{S}$ NLV040

Las Vegas, NV 89193-8521

U.S. Department of Energy

National Nuclear Security Administration

1 (Uncontrolled)

Nevada Operations Office

Technical Information Resource Center

P.O. Box $98521 \mathrm{M} / \mathrm{S} 505$

Las Vegas, NV 89193-8521

\section{Bechtel Nevada}

Correspondence Control

1 (Uncontrolled)*

Bechtel Nevada

P.O. Box $98521 \mathrm{M} / \mathrm{S}$ NLV008

Las Vegas, NV 89193-8521

Environmental Management Library

1 (Uncontrolled)*

Bechtel Nevada

P.O. Box $98521 \mathrm{~N} / \mathrm{S}$ NLV080

Las Vegas, NV 89193-8521

Kevin Campbell

1 (Uncontrolled)*

Bechtel Nevada

P.O. Box $98521 \mathrm{M} / \mathrm{S}$ NTS306

Las Vegas, NV 89193-8521

Ann Heidema

1 (Uncontrolled)

Bechtel Nevada

P.O. Box $98521 \mathrm{M} / \mathrm{S}$ NLV022

Las Vegas, NV 89193-8521 


\section{DISTRIBUTION LIST (Continued)}

\section{Bechtel Nevada (continued)}

Ronald Jackson

1 (Uncontrolled)*

Bechtel Nevada

P.O. Box $98521 \mathrm{M} / \mathrm{S}$ NTS306

Las Vegas, NV 89193-8521

Wayne Johnson

1 (Uncontrolled)*

Bechtel Nevada

P.O. Box $98521 \mathrm{M} / \mathrm{S}$ NTS306

Las Vegas, NV 89193-8521

Steve Nacht

Bechtel Nevada

1 (Uncontrolled)*

P.O. Box $98521 \mathrm{M} / \mathrm{S}$ NTS306

Las Vegas, NV 89193-8521

\section{IT Corporation}

Lynn Kidman

IT Corporation

P.O. Box $93838 \mathrm{M} / \mathrm{S} 439$

Las Vegas, NV 89193-8521

Garry Romano

IT FFACO Support Office

IT Corporation

P.O. Box 93838 M/S 439

Las Vegas, NV 89193-8521

1 (Uncontrolled)*

\section{State Of Nevada}

Manager, Northern Nevada

FFACO Public Reading Facility

1 (Controlled) \&

Nevada State Library and Archives Federal Publications

1 (Uncontrolled)

100 North Stewart Street

Carson City, NV 89701-4285 